\title{
Evolutionary affiliation of the marine nitrogen-fixing cyanobacterium Trichodesmium sp. strain NIBB 1067, derived by 165 ribosomal RNA sequence analysis
}

\author{
Annick Wilmotte, $†$ Jean-Marc Neefs and Rupert De Wachter \\ Author for correspondence: Rupert De Wachter. Tel: +32382023 19. Fax: +3238202248 . \\ e-mail: DWACHTER@REKS.UIA.AC.BE
}

Department of Biochemistry, University of Antwerp (UIA), Universiteitsplein 1, B-2610 Antwerp, Belgium

\begin{abstract}
The 165 rRNA sequence of Trichodesmium sp. strain NIBB 1067 was determined and used for the construction of a distance tree and bootstrap analysis. The tree shows that, among the available cyanobacterial 165 rRNA sequences, Trichodesmium NIBB 1067 has Oscillatoria PCC 7515 as its closest relative, presenting $94.9 \%$ of sequence similarity with the latter strain. This is in contrast to a difference of $9 \mathrm{~mol} \% \mathbf{G}+\mathrm{C}$ in mean genomic DNA base composition between the two organisms. Nevertheless, the genotypic heterogeneity presented by a number of strains assigned to the genus Oscillatoria hinders a taxonomic decision on the separate existence of the genera Trichodesmium and Oscillatoria. The sequence of the internal transcribed spacer (ITS) between the 165 and 235 rRNA genes was also determined, as a possible marker to study inter- and intraspecific variability. The ITS contains the genes coding for tRNAle and tRNA Ala and its total length is 547 nucleotides. In six out of eight sequenced clones, there is a duplication of 29 nucleotides, surrounding the 5' end of the tRNAlle.
\end{abstract}

Keywords: Trichodesmium, $16 \mathrm{~S}$ rRNA sequence analysis, taxonomy, cyanobacteria, internal transcribed spacer

\section{INTRODUCTION}

Trichodesmium species are marine planktonic cyanobacteria which produce extensive blooms at the surface of tropical and subtropical oceanic waters. Their morphology is typical of the filamentous Oscillatoriaceae, which possess simple trichomes with cells dividing in a single plane. The ultrastructure of Trichodesmium erytbraeum (Van Baalen \& Brown, 1969) is quite similar to that of Trichodesmium thiebautii (Gantt et al., 1984) and both exhibit the Oscillatoria-type wall features (Drews \& Weckesser, 1982). They contain gas vesicles to regulate their buoyancy (Walsby, 1981). The pigments present are phycocyanin

\footnotetext{
†Present address: Laboratory of Genetics and Biotechnology, Vlaamse Instelling voor Technologisch Onderzoek, Boeretang 200, B-2400 Mol, Belgium.

Abbreviation: ITS, internal transcribed spacer.

The EMBL accession numbers for the nucleotide sequence data reported in this paper are X70767 and X72871, for the 165 gene and the ITS, respectively.
}

and a phycourobilin-containing phycoerythrin (Fogg, 1987).

Although they do not form heterocysts, Trichodesmium species are able to fix nitrogen aerobically in the light, and may be responsible for up to a quarter of the total nitrogen fixation in the oceans (Capone \& Carpenter, 1982). The contiguous arrangement of nitrogenase genes in Trichodesmium sp. strain NIBB 1067 is typical of nonheterocystous cyanobacteria (Zehr et al., 1991a).

The taxonomy of Trichodesmium and its relation to the genus Oscillatoria is problematic. Different opinions can be found in the literature, depending on the taxonomic weight given to the two morphological features which can be used to separate the two genera: (1) aggregation in macroscopic colonies forming bundles with parallel or radial arrangement of trichomes held together by a thin mucilaginous layer; and (2) gas vacuoles arranged as peripheral cylinders and made up of unusually strong gas vesicles (Walsby, 1981; Fogg, 1987). Umezaki (1974) observed that Trichodesmium contains more fatty acids of low molecular mass than Oscillatoria species usually do. 
The overall morphological similarity of the two genera has prompted some authors (Geitler, 1932; Sournia, 1968) to transfer Trichodesmium to Oscillatoria, whereas others (Gomont, 1892; Golubić, 1977; Anagnostidis \& Komárek, 1988; Castenholz, 1989) have supported the retention of the genus Trichodesmium. The evolutionary affilitation of the genus Trichodesmium and its systematics are thus still a matter of debate.

Cultivation of Trichodesmium species is extremely difficult and until now only the strain NIBB 1067, isolated from Kuroshio waters (Japan), has been grown successfully in laboratory culture (Okhi et al., 1986). A sequence of 359 nucleotides from the nif $\mathrm{H}$ gene of this cultivated strain presents a similarity of $98 \%$ with the homologous sequence from a natural assemblage of $T$. thiebautii from the Caribbean Sea (Zehr et al., 1990). To determine the genotypic relationship of this strain with other cyanobacteria, the 16S rRNA sequence of strain NIBB 1067 was determined and used to build a distance tree containing all. available complete and partial cyanobacterial sequences having at least 686 positions. In addition, the sequence of the internal transcribed spacer (ITS) following the $16 \mathrm{~S}$ rRNA gene was determined.

\section{METHODS}

Genomic DNA was kindly provided by Dr K. Ohki, National Institute of Basic Biology, Okazaki, Japan. Amplification by the polymerase chain reaction (PCR) of a fragment of the rRNA operon comprising the $16 \mathrm{~S}$ rRNA, the I'TS and the $5^{\prime}$ end of the 23S rRNA, was carried out with primers 1 and 18 (Wilmotte $e t$ al., 1993). In a total volume of $100 \mu \mathrm{l}$, the PCR mix contained about $5 \mathrm{ng}$ genomic DNA, $2.8 \mathrm{ng} \mathrm{\mu l}^{-1}$ of primers, $200 \mu \mathrm{M}$ of each dNTP, $2.5 \mathrm{U}$ of Taq DNA polymerase, $10 \mathrm{mM}$ Tris $/ \mathrm{HCl}$, $50 \mathrm{mM} \mathrm{KCl}, 1.5 \mathrm{mM} \mathrm{MgCl}_{2}, 0.01 \%$ (w/v) gelatin, $\mathrm{pH} 8.3$. An initial denaturation of $1 \mathrm{~min}$ at $94{ }^{\circ} \mathrm{C}$ was followed by 25 cycles comprising $1 \mathrm{~min}$ at $94^{\circ} \mathrm{C}, 1 \mathrm{~min}$ at $55^{\circ} \mathrm{C}$ and $3 \mathrm{~min}$ at $72^{\circ} \mathrm{C}$. An incubation of $7 \mathrm{~min}$ at $72^{\circ} \mathrm{C}$ was added to the last cycle. The PCR product was purified by gel electrophoresis in agarose and cloned into vector $\mathrm{pSK}^{+}$(Stratagene) to which a ddT-tail had been added at the $3^{\prime}$ end by terminal deoxynucleotidyl transferase (Holton \& Graham, 1991). Colony hybridization was performed after transformation into competent Escherichia coil strain DH5 $\alpha$, as described previously (Wilmotte et al., 1993).

From 227 colonies which hybridized with the PCR product, eight recombinant clones were randomly chosen and pooled for the sequencing reactions. The sequence determination was carried out using the Sequenase 2.0 kit (USB) following the manufacturer's instructions. Eighteen primers annealing to evolutionarily conserved areas (Wilmotte et al., 1993), a primer with the sequence CGCTCTACCARCTGAGCTA annealing to a region of the tRNA ${ }^{\text {Ala }}$ (primer 19), and two primers complementary to the M13 sites on the vector were used to sequence both strands of the $16 \mathrm{~S}$ rRNA gene, the ITS and the $5^{\prime}$ end of the $23 \mathrm{~S}$ rRNA gene. In addition, the first 350 nucleotides of the ITS sequence were determined separately for all eight clones using the $\Delta$ Taq cycle-sequencing kit (USB) wita primer 14 (Wilmotte et al., 1993). The latter kit was also used to sequence directly the first 490 nucleotides of the ITS with primers 14, 17 and 19 after purification of the PCR product by electrophoresis.
The new $16 \mathrm{~S}$ rRNA sequence was fitted into an alignment (Neefs et al., 1993) containing all published complete or nearly complete bacterial 16S rRNA sequences, plus a number of partial cyanobacterial $16 \mathrm{~S}$ rRNA sequences. For each pair of aligned sequences, distance values were calculated, corrected for multiple mutations by means of the formula of Jukes \& Cantor (1969) as previously described (Van de Peer et al., 1990), and entered into a distance matrix. A distance tree was constructed by means of the neighbour-joining method of Saitou \& Nei (1987). Confidence values for individual nodes of the resulting tree were determined by a bootstrap analysis (Felsenstein, 1985), in which 500 bootstrap trees were constructed using randomly resampled data. This data analysis was carried out with the software package treecon (Van de Peer \& De Wachter, 1993).

\section{RESULTS AND DISCUSSION}

The complete 16S rRNA sequence was obtained, except for an estimated 27 nucleotides at the $5^{\prime}$ end. This corresponds to 1471 nucleotides.

Fig. 1 shows a distance tree constructed from all cyanobacterial $16 \mathrm{~S}$ rRNAs for which the complete sequence or an appreciable fraction of it is known. All available cyanobacterial sequences were used because selection of strains may cause changes in the topology of the tree. In this tree, Trichodesmium NIBB 1067 appears closely related to Oscillatoria PCC 7515, for which a partial $16 \mathrm{~S}$ rRNA gene sequence is known (Giovannoni et al., 1988). The grouping of the two strains is statistically supported at a level of $100 \%$ by the bootstrap analysis. Oscillatoria PCC 7515 is quite different in morphology and physiology from Trichodesmium sp., being a freshwater strain isolated from a greenhouse water tank in Sweden, with discoid cells that have a diameter of $15 \mu \mathrm{m}$. It is able to synthesize nitrogenase anaerobically (Rippka et al., 1979), and is the reference strain of the genus Oscillatoria as defined in Bergey's Manual of Systematic Bacteriology (Castenholz, 1989). By comparison, the average cell width of Trichodesmium NIBB 1067 is $7.5 \mu \mathrm{m}$ and the cell length varies between 5.4 and $5.7 \mu \mathrm{m}$ in culture (K. Okhi, personal communication). Although the mean DNA base composition of Oscillatoria PCC 7515 is $40 \mathrm{~mol} \% \mathrm{G}+\mathrm{C}$ (Herdman et al., 1979) and is greater than that (31 mol \%) of Trichodesmium NIBB 1067 (Zehr et al., 1991b), the base compositions of the determined $16 \mathrm{~S}$ rRNA sequences are very similar (55.3 and $54.3 \mathrm{~mol} \% \mathrm{G}+\mathrm{C}$, respectively) and fall within the variation range observed for 12 cyanobacterial sequences (52.7-56.5 mol \%) (unpublished data).

For the 994 nucleotides available for comparison, the $16 \mathrm{~S}$ rRNA sequence similarity between the two strains is $94.9 \%$. There is not yet a well-agreed relation between 16S rRNA sequence similarities and taxonomic levels, whereas DNA-DNA hybridization percentages are currently used to recognize conspecific and congeneric proteobacteria (Wayne et al., 1987). However, a $16 \mathrm{~S}$ rRNA sequence similarity of $94.9 \%$ is clearly too low to indicate conspecificity. We propose to retain the generic name Trichodesmium for strain NIBB 1067 because of the difference in mean DNA base composition and because it would not be practical to add this well-characterized genus to a taxon with a problematic phylogeny. Indeed, 
Fig. 1. Distance tree based on partial $16 \mathrm{~S}$ rRNA sequence analysis of Trichodesmium sp. strain NIBB 1067, and 45 other complete and partial cyanobacterial sequences published to date (Britschgi \& Giovannoni, 1991; Giovannoni et al., 1988, 1990; Ligon et al., 1991; Tomioka \& Sugiura, 1983; Turner et al., 1989; Urbach et al., 1992; Weller et al., 1991, 1992; Wilmotte et al., 1992, 1993), Marchantia polymorpha plastid (Ohyama et al., 1986), Cyanophora paradoxa cyanelle (V. L. Stirewalt \& D. A. Bryant, unpublished data) and Escherichia coli (Brosius et al., 1981) which was used to root the tree. Names beginning with SAR and OS designate organisms isolated directly from environmental samples (Britschgi \& Giovannoni, 1991; Giovannoni et al., 1990; Weller et al., 1991, 1992). From the alignment, available from the authors, 686 positions common to the 49 sequences were used for tree construction. They correspond to Escherichia coli positions 254-507, 676-892, 1121-1312. The distance between two organisms, expressed in substitutions per nucleotide, is obtained by summing the lengths of the horizontal branches connecting them, using the scale at the top. Numbers at nodes indicate the frequency with which the cluster descending from that node was found in the 500 bootstrap trees. Only bootstrap percentages higher than $50 \%$ are given. The position of the root was chosen to equalize its distance to the outgroup, E. coli, and its average distance to all other included organisms. the dispersal of the Oscillatoria strains in different lineages (Fig. 1) indicates that this genus is genotypically heterogeneous.

The ITS sequence given in Fig. 2 contains genes coding for tRNA ${ }^{\text {Ile }}$ and $t R N A^{A l a}$, as observed in several eubacteria including the cyanobacterium Synechococcus sp. strain PCC 6301 (Tomioka \& Sugiura, 1984), and in plastids (Graf et al., 1980; Ohyama et al., 1986). In six out of the eight independently sequenced clones, it shows a duplication of 29 nucleotides involving 14 nucleotides upstream of the tRNA ${ }^{\text {Ile }}$ and the first 15 nucleotides of the tRNA ${ }^{\text {Ile }}$. In addition, the direct cycle sequencing of the PCR product confirmed that there was a mixture of ITS sequences with and without duplication because the sequence obtained with primers situated upstream and downstream of the duplication became unreadable beyond one copy of the duplicated sequence. Other differences among the eight independently sequenced clones were found at positions 191, 328 and 339 (Fig. 2). All of these were observed in single clones, and they may represent microheterogeneities or misincorporations by the Taq polymerase, except for the difference at position 328 which was shared by the two clones without duplication. Five clones had an identical sequence and three had a deviant sequence. Assuming that the differences are due to sequence heterogeneity, the presence of a minimum of four cistrons would be derived. The copy number of the rRNA cistrons in Trichodesmium sp. has not been determined because prohibitive amounts of pure DNA would be necessary but two, five and six copies were observed for other cyanobacteria (Nichols et al., 1982). The first 395 nucleotides from the two copies of the ITS of Synechococcus PCC 6301 have been sequenced independently (Williamson \& Doolittle, 1983; Tomioka \& Sugiura, 1984). Only four insertions and two deletions were observed, and Tomioka \& Sugiura (1984) concluded that the $r r n$ operons were highly conserved.

The conserved region from positions 435 to 460 of the 


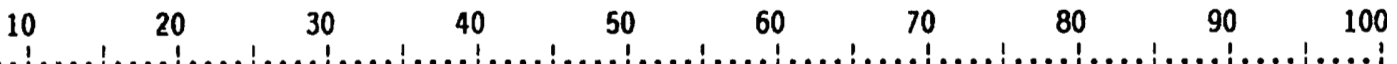

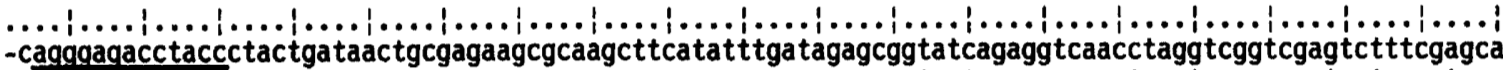
S -cagggagacctaccctactgataactgcgagaagcgcaagcttcatat tgatagagcggtatcagaggtcaacctaggtcggtcgagtctt tcgagca

$\begin{array}{llllllllll}110 & 120 & 130 & 140 & 150 & 160 & 170 & 180 & 190 & 200\end{array}$

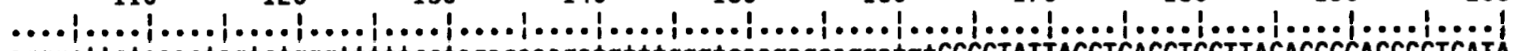

S agggcttctaaactagtctgggtttttcctagacaaagatgtttgggtcaagagcaggatgtGGGCTATTAGCTCAGGTGGTTAGAGCGCACCCCTGATA

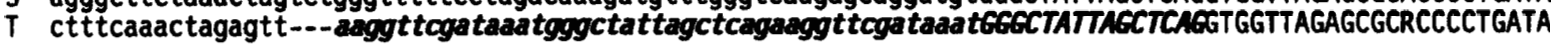

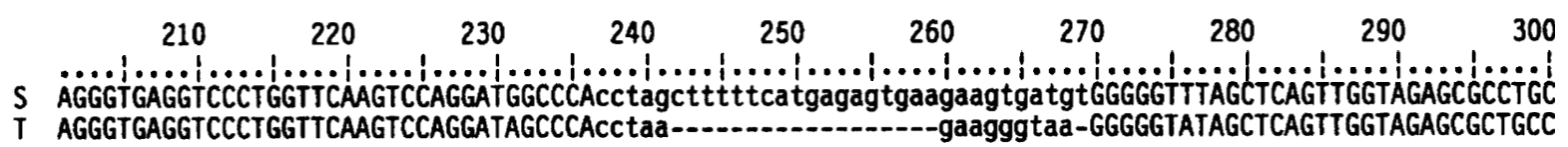

AGGGTGAGGTCCTGGTTCAAGTCCAGGATAGCCCACCtaa-........----oagggtaa-GGGGGTATAGCTCAGTTGGTAGAGCGCTGCC

$\begin{array}{llllllllll}310 & 320 & 330 & 340 & 350 & 360 & 370 & 380 & 390 & 400\end{array}$

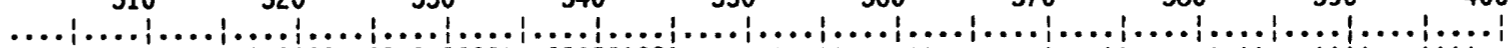

S TTIGCAAGCAGGATGTCAGCGGTTCGAGTCCGCTAACCTCCACCAaaagactgcttaaaattcaaaaaatcagttcagcatcttaagttttcgattttcg

T TITGCAAGGCAGAAGTCAGCGGTTCGAKTCCGCTTACCWCCAGGAataaaaaaggtagaaatcagcaacaagacctgaataaagcaaagcaagtcatgct

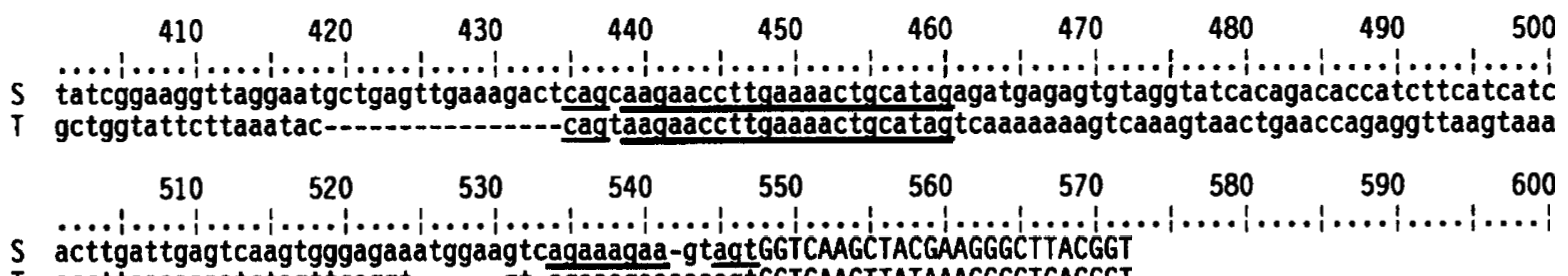

$T$ acct taaaaaaatctagttcaggt-..-.-gt-agaaagaaaaaagt GGTCAAGTTATAAAGGGCTGACGGT
\end{abstract}

\begin{abstract}
Fig. 2. Alignment of the ITS sequences from two cyanobacterial species. S, Synechococcus PCC 6301 ('Anacystis nidulans') (Tomioka \& Sugiura, 1984); T, Trichodesmium NIBB 1067. Nucleotides which are not identical in eight independently sequenced clones are indicated according to the ambiguity codes of the International Union of Biochemistry (1985). Upper-case characters are used for the tRNA ${ }^{\text {lle }}$ (positions 163-236), tRNAAla (positions 270-345) and the 5' end of the 23S rRNA (positions 548-572). The rRNA termini are assumed to be in homologous positions to those determined for Synechococcus PCC 6301 (Tomioka \& Sugiura, 1983, 1984). In most of the ITS, the sequences are so variable that no meaningful alignment is possible. Therefore the nucleotides, indicated in lower-case, are generally written contiguously to minimize the space between the genes. Areas of sequence conservation in the ITS are underlined. The duplication of 29 nucleotides is indicated in bold italics.
\end{abstract}

ITS (Fig. 2) is noteworthy because it is also observed in seven other cyanobacterial ITS sequences (our unpublished data). This sequence conservation in the middle of a variable region may indicate that it has a function, such as in the processing of the rRNA precursor.

Sequence and length are more variable for the ITS than for the 16S rRNA gene, and species-specific probes inferred from the ITS sequence have been used for bacterial identification (Rossau et al., 1992). Therefore, ITS sequences may be useful tools to study inter- and intraspecific variability.

\section{ACKNOWLEDGEMENTS}

We thank Dr Kaori Ohki (National Institute of Basic Biology, Japan) for the kind gift of genomic DNA from Trichodesmium, NIBB 1067 and information, and two anonymous referees for: constructive criticism. A. W. was senior research assistant of the National Fund for Scientific Research during this work.

This research was supported by the Fund for Joint Basic Research and performed in the framework of the Institute for the Study of Biological Evolution of the University of Antwerp.

\section{REFERENCES}

Anagnostidis, K. \& Komárek, J. (1988). Modern approach to the classification system of cyanophytes. 3-Oscillatoriales. Arch Hydrobiol/Suppl 80, 1-4, Algological Studies 50/53, 327-472.

Britschgi, T. B. \& Giovannoni, S. J. (1991). Phylogenetic analysis of a natural marine bacterioplankton population by rRNA gene cloning and sequencing. Appl Environ Microbiol 57, 1707-1713.

Brosius, J., Dull, T. J., Sleeter, D. D. \& Noller, H. F. (1981). Gene organization and primary structure of a ribosomal RNA operon from Escherichia coli. J Mol Biol 148, 107-127.

Capone, D. G. \& Carpenter, E. J. (1982). Nitrogen fixation in the marine environment. Science 217, 1140-1142.

Castenholz, R. W. (1989). Subsection III, order Oscillatoriales. In Bergey's Manual of Systematic Bacteriology, vol. 3, pp. 1710-1806. Edited by J. T. Staley, M. P. Bryant, N. Pfennig \& J. G. Holt. Baltimore: Williams \& Wilkins.

Drews, G. \& Weckesser, J. (1982). Function, structure and composition of cell walls and external layers. In The Biology of Cyanobacteria, pp. 333-357. Edited by N. G. Carr \& B. A. Whitton. Oxford: Blackwell Scientific Publications.

Felsenstein, J. (1985). Confidence limits on phylogenies: an approach using the bootstrap. Evolution 39, 783-791.

Fogg, G. E. (1987). Marine planktonic cyanobacteria. In Tht 
Cyanobacteria, pp. 393-414. Edited by P. Fay \& C. Van Baalen. Amsterdam: Elsevier.

Gantt, E., Okhi, K. \& Fujita, Y. (1984). Trichodesmium thiebautii; structure of a nitrogen-fixing marine blue-green alga (Cyanophyta). Protoplasma 119, 188-196.

Geitler, L. (1932). Cyanophyceae. In Rabenborst's Kryptogamenflora von Deutschland, Österreich und der Schweiz, vol. 14, pp. 1-1196. Leipzig: Akademische Verslagsgesellschaft. Reprinted 1971, New York: Johnson.

Giovannoni, S. J., Turner, S., Olsen, G. J., Barns, S., Lane, D. J. \& Pace, N. R. (1988). Evolutionary relationships among cyanobacteria and green chloroplasts. J Bacteriol 170, 3584-3592.

Giovannoni, S. J., Britschgi, T. B., Moyer, C. L. \& Field, K. G. (1990). Genetic diversity in Sargasso Sea bacterioplankton. Nature $345,60-63$

Golubić, S. (1977). Speciation in Trichodesmium: occupation of an oceanic pelagic niche. Schweiz Z Hydrol 39, 141-143.

Gomont, M. (1892). Monographie des Oscillariées (Nostocaceae homocystées). Ann Sci Nat, Sér Bot 15, 265-368; 16, 91-264. Reprinted 1962, Weinheim, Germany: Cramer.

Graf, L., Kössel, H. \& Stutz, E. (1980). Sequencing of 16S-23S spacer in a ribosomal RNA operon of Euglena gracilis chloroplast DNA reveals two tRNA genes. Nature 286, 908-910.

Herdman, M., Janvier, M., Waterbury, J. B., Rippka, R., Stanier, R. Y. \& Mandel, M. (1979). Deoxy ribonucleic acid base composition of cyanobacteria. J Gen Microbiol 111, 63-71.

Holton, T. A. \& Graham, M. W. (1991). A simple and efficient method for direct cloning of PCR products using ddT-tailed vectors. Nucleic Acids Res 19, 1156

International Union of Biochemistry, Nomenclature Committee (1985). Nomenclature for incomplete specified bases in nucleic acid sequences. European Journal of Biochemistry 150, 1-5.

Jukes, T. H. \& Cantor, C. R. (1969). Evolution of protein molecules. In Mammalian Protein Metabolism, vol. 3, pp. 21-132. Edited by H. N. Munro. New York: Academic Press.

Ligon, P. J. B., Meyer, K. G., Martin, J. A. \& Curtis, S. E. (1991). Nucleotide sequence of a $16 \mathrm{~S}$ rRNA gene from Anabaena sp. strain PCC7120. Nucleic Acids Res 19, 4553.

Neefs, J.-M., Van de Peer, Y., De Rijk, P., Chapelle, S. \& De Wachter, R. (1993). Compilation of small ribosomal subunit RNA structures. Nucleic Acids Res 21, 3025-3049.

Nichols, J. M., Foulds, I. J., Crouch, D. H. \& Carr, N. G. (1982). The diversity of cyanobacterial genomes with respect to ribosomal RNA cistrons. J Gen Microbiol 128, 2739-2746.

Ohki, K., Rueter, J. G. \& Fujita, Y. (1986). Cultures of the pelagic cyanophytes Trichodesmium erytbraeum and $T$. thiebautii in synthetic medium. Mar Biol 91, 9-13.

Ohyama, K., Fukuzawa, H., Kohchi, T., Shirai, H., Sano, T., Sano, S., Umesono, K., Shiki, Y., Takeuchi, M., Chang, Z., Aota, S. I., Inokuchi, H. \& Ozeki, H. (1986). Chloroplast gene organization deduced from complete sequence of liverwort Marchantia polymorpha chloroplast DNA. Plant Mol Biol Rep 4, 148-175.

Rippka, R., Deruelles, J., Waterbury, J. B., Herdman, M. \& Stanier, R. Y. (1979). Generic assignments, strain histories and properties of pure cultures of cyanobacteria. J Gen Microbiol 111, 1-61.

Rossau, R., Michielsen, A., Jannes, G., Duhamel, M., Kersters, K. \& Van Heuverswijn, H. (1992). DNA probes for Bordetella species and a colorimetric reverse hybridization assay for the detection of Bordetella pertussis. Mol Cell Probes 6, 281-289

Saitou, N. \& Nei, M. (1987). The neighbor-joining method: a new method for reconstructing phylogenetic trees. Mol Biol Evol 4, 406-425.

Sournia, A. (1968). La cyanophycée Oscillatoria (= Trichodesmium) dans le plancton marin: taxonomie, et observations dans le canal de Mozambique. Nova Hedwigia 15, 1-12.

Tomioka, N. \& Sugiura, M. (1983). The complete nucleotide sequence of a $16 \mathrm{~S}$ ribosomal RNA gene from a blue-green alga, Anacystis nidulans. Mol \& Gen Genet 191, 46-50.

Tomioka, N. \& Sugiura, M. (1984). Nucleotide sequence of the $16 \mathrm{~S}-23 \mathrm{~S}$ spacer region in the $\operatorname{rrn} A$ operon from a blue-green alga, Anacystis nidulans. Mol \& Gen Genet 193, 427-430.

Turner, S., Burger-Wiersma, T., Giovannoni, S. J., Mur, L. R. \& Pace, N. R. (1989). The relationship of a prochlorophyte, Prochlorothrix hollandica, to green chloroplasts. Nature 337, 380-382.

Umezaki, I. (1974). On the taxonomy of the genus Trichodesmium. Bull Plankton Soc Jpn 20, 93-99.

Urbach, E., Robertson, D. L. \& Chisholm, S. W. (1992). Multiple evolutionary origins of prochlorophytes within the cyanobacterial radiation. Nature 355, 267-270.

Van Baalen, C. \& Brown, R. M. (1969). The ultrastructure of the marine blue green alga, Trichodesmium erythraeum, with special reference to the cell wall, gas vacuoles, and cylindrical bodies. Arch Mikrobiol 69, 79-91.

Van de Peer, Y. \& De Wachter, R. (1993). TREECON: a software package for the construction and drawing of evolutionary trees. Comput Appl Biosci 9, 177-182.

Van de Peer, Y., Neefs, J. M. \& De Wachter, R. (1990). Small ribosomal subunit RNA sequences, evolutionary relationships among different life forms, and mitochondrial origins. $J$ Mol Evol 30, 463-476.

Walsby, A. (1981). Cyanobacteria : planktonic gas-vacuolate forms. In The Prokaryotes, pp. 224-235. Edited by M. P. Starr, H. Stolp, H. G. Trüper, A. Balows \& H. G. Schlegel. Berlin: SpringerVerlag.

Wayne, L. G., Brenner, D. J., Colwell, R. R., Grimont, P. A. D., Kandler, O., Krichevsky, M. I., Moore, L. H., Moore, W. E. C., Murray, R. G. E., Stackebrandt, E., Starr, M. P. \& Trüper, H. G. (1987). Report of the ad hoc committee on reconciliation of approaches to bacterial systematics. Int J Syst Bacteriol 37, 463-464.

Weller, R., Walsh Weller, J. \& Ward, D. M. (1991). $16 S$ rRNA sequences of uncultivated hot spring cyanobacterial mat inhabitants retrieved as randomly primed cDNA. Appl Environ Microbiol 57, 1146-1151.

Weller, R., Bateson, M. M., Heimbuch, B. K., Kopczinski, E. D. \& Ward, D. M. (1992). Uncultivated cyanobacteria, Chloroflexuslike inhabitants, and spirochete-like inhabitants of a hot spring microbial mat. Appl Environ Microbiol 58, 3964-3969.

Williamson, S. E. \& Doolittle, W. F. (1983). Gene for tRNA ${ }^{\text {tle }}$ and tRNA $^{\text {Ala }}$ in the spacer between the $16 \mathrm{~S}$ and $23 \mathrm{~S}$ rRNA genes of a blue-green alga: strong homology to chloroplast tRNA genes and tRNA genes of E. coli rrnD cluster. Nucleic Acids Res 11, 225-235.

Wilmotte, A., Turner, S., Van de Peer, Y. \& Pace, N. R. (1992). Taxonomic study of marine oscillatoriacean strains (cyanobacteria) with narrow trichomes. II. Nucleotide sequence analysis of the $16 \mathrm{~S}$ ribosomal RNA. J Pbycol 28, 828-838.

Wilmotte, A., Van der Auwera, G. \& De Wachter, R. (1993). Structure of the $16 \mathrm{~S}$ ribosomal RNA of the thermophilic cyanobacterium Chlorogloeopsis HTF ('Mastigocladus laminosus HTF') strain PCC7518, and phylogenetic analysis. FEBS Lett 317, 96-100.

Zehr, J. P., Limberger, R. J., Ohki, K. \& Fujita, Y. (1990). Antiserum to nitrogenase generated from an amplified DNA fragment from 
natural populations of Trichodesmium spp. Appl. Environ Microbiol 56, 3527-3531.

Zehr, J.P., Ohki, K. \& Fujita, Y. (1991a). Arrangement of nitrogenase structural genes in an aerobic filamentous nonheterocystous cyanobacterium. J Bacteriol 173, 7055-7058.

Zehr, J.P., Ohki, K., Fujita, Y. \& Landry, D. (1991b). Unique modification of adenine in genomic DNA of the marine cyanobacterium Trichodesmium sp. strain NIBB 1067. J Bacteriol 173, 7059-7062.

Received 19 November 1993; revised 11 February 1994; accepted 22 February 1994. 